\title{
Rethinking Archival Ethics
}

\author{
Richard J. Cox \\ School of Information Sciences \\ University of Pittsburgh \\ February 2013 \\ Draft
}

Introduction. Ethics has been a persistent topic within the American archival community for more than a half-century, much of it treated, until recently, in the most benign matter (by this I mean that it has been a topic assumed to be important for symbolic reasons but not to possess any substantial practical value in the archivist's daily work). The earliest discussions were mostly about an ethics code, presented almost always as key to claiming that archivists represented not just a community but a profession, and for some, even a discipline (the disciplinary claims have come as a more theoretical and scholarly literature has taken root). We moved from a statement that could be framed and hung on a wall to a more intricate document with specifics encompassing even advising archivists what to do when they discovered a breach of moral conduct. Would that the discussions had stopped there. Within a relatively brief time the ethics code moved full circle from being an ornamental wall hanging to what became termed an aspirational document, something intended to help archivists understand the ethical dimensions of their work but without fear of censure or other actions if they wandered outside of the parameters of ethical behavior; in other words, the code is intended to give something archivists can aim at but not fret too much if they fall short. 
If we examine the professional literature of the 1970s and 1980s, when most of the formative discussion about an ethics code emerged, we can detect some fissures in the ethical foundations of professional practice. In my own essay on professionalism in the mid-1980s, I ended it with a comment that archivists had to understand that being professional required both authority and power." Even though, just a short time after, archivists began reading about the implicit power of recordkeeping and information systems, ${ }^{\text {iii }}$ American archivists generally found it repugnant that they would wield any degree of power. The real substance of issues about power actually emerged within the archival community and its professional associations. While the Society of American Archivists continued to refine its ethics code, these refinements gutted any sense of an ethics process. and the Society's actions in other ways suggested that it had little intention of pursuing an ethical agenda. Debates about the appropriateness of a labor poster on the cover of the American Archivist, access to the records of the Office of Presidential Libraries, and the Protocols for Native American Archival Materials, just to name a few recent cases, have all attested to the significance of ethics as a professional concern and the limitations of American archivists to frame appropriately this topic. ${ }^{\text {iv }}$

It is not my intent, in this brief essay, to rehash the substance of these debates, especially since I have written about these matters elsewhere. My purpose here is to identify some elements of what I see as the unfinished work on archival ethics, and what I have selected to discuss relate to my personal interests and concerns (others would select different topics or will disagree with my choices). My hope is that what I have 
written here will continue to spur on new discussion, and, in fact, some of my observations may seem to some as being a bit far-fetched (concerning issues and concerns not normally commented on in this context). It is the nature of archival ethics, now at least, to be controversial (mainly because it forces practicing and prospective archivists out of their comfort zones). The ethics of archival work looms into the future as one of the most important professional issues, permeating every aspect of what archivists do, even our efforts to manage born-digital evidence systems or to select what analog documents will be digitized. The technical challenges of such digital stewardship work, long attested to as the greatest challenges facing archivists, may pale in comparison to the ethical aspects these systems generate.

The Empty Shell of an Ethics Code. Let's begin with the obvious. We need to develop a process for investigating ethics violations, as not having a process leaves the code as little more than an empty shell. While other professional associations, such as the American Historical Association, have backed off from investigating the increasing numbers of plagiarism cases and other such improprieties in favor of referring them to the universities and colleges employing the alleged offenders, it is difficult to perceive this as a reasonable solution for archival ethics (the small scale of archives faculty numbers, the modest profile of all but a few of these programs, and the immersion of these programs mostly as specializations within other degrees all work against this as a realistic approach). Elena Danielson's comment that one of the greatest challenges in this area of archival labor is to provide some acknowledgement of the reasonableness of those who argue for some kind of enforcement mechanisms is both illuminating and 
disturbing. ${ }^{\vee}$ Not making provision for individuals with this perspective only leads to disaffecting them (although the number of such individuals seems to be small).

At the moment, I am a disaffected SAA member, not quite willing to resign or not renew my membership, but also not feeling that SAA is my professional home (my home now seems to be the Archival Education Research Initiative [AERI], but who knows what it will become or how long it will last); despite my disaffection, and to be consistent, I feel it is unethical to be a practicing American archivist or archival educator without being a member of the national professional association. While SAA seems inclined to believe that ethics is a soft or vague idea where everyone's opinion is equal to everyone else's or worried about the legal implications of any possible action SAA might take, such a posture dilutes the substance of professionalism SAA could endorse. Mind you, I am not advocating the establishment of tribunals or a form of truth commission; I am only suggesting that SAA can, and should when necessary, issue informed statements expressing an opinion or assessment of a situation involving the mismanagement, destruction, or obstruction of archival materials. It also can censure any individual SAA member for actions deemed unethical. Some will read this as a proposal for an archives police state (and that is definitely not my purpose); but without some ability to identify archival rights and wrongs, we have nothing but platitudes, wishes, and hopes.

Archival Employment and the Production of Archivists. One of the great new ethical issues of our time, although few seem to see it this way, is our overproducing new archivists in a depressed job market, a difficult topic for an archival educator who is 
often under pressure to fill as many seats as possible in his classroom. When the gap between new students and open positions widened, some archivists and wannabe archivists took to blogs and listservs to protest this situation, some blaming archival professors, in conspiratorial terms, with the creation of this problem (or, at least, lying about the prospects for getting a professional position). It is, of course, much more complicated than this. On the one hand, universities, especially in the past two decades, have become money-making corporate entities, creating educational programs to meet societal and other needs by guaranteeing individuals, who pay increasingly outrageous amounts of money, that they will get good jobs for their investment; academic units that are not generating money or placing graduates in positions (such as classics departments, museum studies programs, and other humanities-focused programs) are threatened and even shut down and having their resources shifted to engineering, science, and technology units). While many aspects of these schools have become so consumed with the financial bottom-line that they lost sight of the public good, it is, of course, nothing wrong with being fiscally responsible. But faculty have found themselves needing to grow programs to sell as many seats in the classroom, real and virtual, as fast as they can.

And this fixation on growth has become, in my opinion, an ethical issue. We don't really need all these archivists as much as we need better, more visionary, and exemplary archivists to carry the important message of the value of archives into the world. At my school, in the archives program alone, we developed more strict and selective admissions criteria for this purpose. And we have encouraged some who want 
to come and spend a small fortune to become an archivist not to come, but to seek entry-level, archival technician positions without spending so much money (after they garner such experience then they might discover the need to come for a more advanced education). We have a long way to go with this, and it is possible that ultimately the university administration will tell us to cease and desist. In the meantime, I believe we have the opportunity to not just talk about ethics but to act ethically by trying to develop an educational program intending to produce archival scholars, administrators, and leaders who possess a strong sense of ethical principles in all that they do. ${ }^{\mathrm{vi}}$

The Challenge of Distance Education. One deliberate step I have been involved in our school has been withdrawing our graduate archival education program from distance education, which definitely has us moving in the opposite direction of most schools offering such programs. Is this an ethical issue? It is, at least partly, an ethical issue (in my opinion). The proliferation of online archival education programs has led to larger groups of graduates entering the job market at a time when there is already a larger number of applicants searching for a shrinking quantity of openings. More importantly, what is the actual quality of the distance courses? Do they provide an opportunity to immense students into understanding archival knowledge? Are they limited to training rather than educating individuals to become archivists? And the questions and issues can go on, but at the moment they have hardly been raised. The distance programs keep proliferating, each promising to make archivists in a convenient manner. There is an element of selling credentials, since the primary focus seems to be on the convenience of completing these programs not really on the quality of the 
curriculum, the reputation of the graduate program, or the placement of it's graduates. But then again, higher education has always been a checkered landscape of strengths and weaknesses, successes and failures. This is what we have to navigate, and it is not the main point of this essay. I remain convinced that we need to equip our students not only to understand archival knowledge, but for them to be able to contribute to archival knowledge. I believe this is best nurtured face-to-face, but I am willing to be proved wrong. Besides, this may sort itself out when the existence of so many online graduate programs eliminates the financial benefits to the schools offering them and forces them to focus on their distinctive academic qualities for the preparation of new archivists.

Defining the Archival Mission. Essential to sorting through whether such issues are ethical or not depend on our ability to ask and answer some larger questions. For example, we need to develop stronger clarity about our archival mission and the notion of personal calling in order to carry out this mission. ${ }^{\text {vii }}$ Why is this so crucial? There are two reasons. First, archivists have been fuzzy in their defining of archives and its mission. Some say the mission is to document society, others argue it is to preserve evidence for the purposes of accountability and memory, and, then, still others speak of and write about the value of archives for everything from social justice through notions like the public good and cultural identity issues. So, archivists tend to pick and choose from all these tenets (and others) as they feel so inclined, led, interested, or provoked. Second, given the weakness of professional ethics codes, the individual archivist must have sorted out for him- or herself their own personal sense of morality. Apparently, this is harder than we imagine, especially as the present generation seems either to have 
ignored such matters or have adopted pluralistic approaches that dump them in the same basket. In other words, archivists are adrift when it comes to grappling with the specifics of ethical practice. And being adrift is not a good thing for resolving disputes about alleged unethical behavior or for working in a networked world where ethical, legal, and other problems are more likely to occur and to become public matters. Having everyone speaking at cross purposes leads us only to what can, at best, be termed a muddle. We need to do better than this, and we can, if we stop fussing with each other and turn our eyes to a distinctive and profound public good position.

Defining Personal Standards. In our world of crowd-sourcing and the Cloud, maybe we also need to start something equivalent to the MBA Oath movement, whereby professors and students reacted to the growing revelations about business improprieties and started a voluntary movement for business school students to pledge ethical behavior in their future careers and places of employment. Of course, the oath movement thrived in an environment whereby the MBA degree seems to have lost its value, needing to be "redefined." "Today, no one knows what it really means. Among business schools there is no common body of knowledge mastered by students, no agreed-upon number of credit hours required, and no formal licensure offered." "viii It is too soon to ascertain what the long-term benefit of this movement is but we can certainly assume that creating a new business ethic is positive. Given the weak status of SAA's code and the association's interest in keeping the code as a reference only, should we start an Archival Oath movement? Since there is a stronger, although not definitive, sense of what archival knowledge consists of, it might be easier to assemble 
the elements of an equivalent movement in this professional community. This moves the focus from association platitudes and various internal political squabbles about what an ethics code should be to one that is squarely on the shoulders of individuals. Since there are some graduate archival education programs, like mine, already supporting a curriculum with a strong ethics stress, we are poised to be able to do this. Although how many graduate archival education programs possess strong ethical emphases is not really known (and some investigation ought to be made in this area).

Religion and Archival Ethics. Finally, and on a more personal note, we need to have some discussion about how to introduce a religious element into archival ethics. I started thinking about this in recent years as I listened to conference presentations, read the professional and scholarly literature, and entered into conversations with archivists across North America and throughout the world. I often heard individuals discuss postmodern perspectives and other philosophies as if they are "real" things, but while carefully bypassing other potential and important topics for ethics such as religion. A theory is useful, and often essential, for building the scaffolding of knowledge about archives and recordkeeping. As a Christian I also have seen a recent movement to relate faith issues to real world or work matters, pushing me to think about a kind of "archival theology," principally moving religious values back into ethics. ${ }^{\mathrm{ix}}$ Some reading this will run screaming away in confusion and fear. Historically, however, the JudeoChristian worldview has had a tremendous influence on the shaping of personal ethics (and it may be essential to helping individual professionals cope with such challenges when there is no one else or group to assist them. 
I am not arguing that this should become the principal focus of any professional ethics, but there is no reason why this way of seeing things should be ignored, especially as religion is becoming more prominent again in the university. As the authors of a recent study describe this, "Giving more careful attention to religion (broadly construed) has the possibility of enhancing the work of higher education in untold ways, because religion is inextricably blended into the key dispositions that drive learning itself - the mixing of critical thinking with hope, the awareness of difference, the ability to wonder and to see the world in new ways, the skill of focusing on one thing at a time, and the blending of the blending of the personal with the impersonal. Attending to religion can enliven all of these dimensions of higher learning; ignoring religion undermines them." Helping people understand that personal morality, especially crucial for anyone contemplating becoming a whistleblower -- and knowing what that means -is essential to being an ethical professional (and religion is one important way of figuring this out).

Conclusion. Ethical issues in the archival profession have become a much more significant topic than anyone could have ever predicted, even just a decade or two ago. It is also a topic that has outraced professional structures and the complexities of dealing with information and recordkeeping technologies. However, there is hope that the next generation of archivists will be better prepared to cope with these tricky matters. A small number of graduate programs are seeking to prepare their graduates for dealing with ethical issues and, hopefully, some will become leaders in preparing the profession to resolve such matters. There is considerable work to be done here, but, at 
least, the work is compelling, important, and, at times, inspirational. For myself, I only hope I live long enough to see progress and that I act ethically when debating ethical concerns. While I am not an ethicist, theologian, or philosopher, I recognize the importance of records in our society and can discern that this value often involves ethical issues and that we discover such matters almost everywhere we look. Reading a recent study of the looting of antiquities, I found this statement about the records of the Getty Museum: In the case of the Getty and its activities in the looted antiquities trade, the authors of a study note, "The backbone of this account is a trove of thousands of pages of confidential Getty records provided by half a dozen key sources at various levels of the institution. . . . These records were provided by sources who risked their careers and reputations for the public's right to know the truth. This account would not have been possible without them. ${ }^{1{ }^{11}}$ Such a statement suggests why someone like Danielson urges the archival community to come to grips with how we need an ethics process addressing the needs of people who may find themselves in such a position and why someone like keeps teaching and writing ethical concerns. Archival ethics is not some theoretical issue, but one of the utmost practical value that most archivists will face at some point in their careers.

${ }^{\mathrm{i}}$ The best book on the topic is Elena S. Danielson, The Ethical Archivist (Chicago: Society of American Archivists, 2010). For my own views see my Ethics, Accountability, and Record Keeping in a Dangerous World (London: Facet Publishing, 2006) and Archival Anxiety and Vocational Calling_(Duluth, MN: Library Juice Publications, 2011). 
${ }^{i i}$ Richard J. Cox, "Professionalism and Archivists in the United States," American Archivist 49 (Summer 1986): 229-247.

${ }^{\text {iii }}$ For a recent example of a study linking writing, recordkeeping, and societal and political power see Kathryn Burns, Into the Archive: Writing and Power in Colonial Peru (Durham: Duke University Press, 2010).

${ }^{\text {iv }}$ I have discussed these cases (and other cases) in my two books on ethics.

$\mathrm{v}$ "If the profession continues the policy of providing an aspirational code rather than enforcing ethics with penalties, there needs to be a forum for the concerns of archivists who take a different view"; Danielson, Ethical Archivist, p. 40.

${ }^{\text {vi }}$ I have written about the issues of professional schools and the corporate university in my The Demise of the Library School: Personal Reflections on Professional Education in the Modern Corporate University (Duluth, MN: Library Juice Publications, 2010).

vii This is a topic I have wrestled with in my Archival Anxiety and the Vocational Calling (Duluth, MN: Litwin Books, 2011).

${ }^{\text {viii }}$ Max Anderson and Peter Escher, The MBA Oath: Setting a Higher Standard for Business Leaders (New York: Portfolio, the Penguin Group, 2010), p. 18.

${ }^{\text {ix }}$ An example of this new emphasis is Tom Nelson, Work Matters: Connecting Sunday Worship to Monday Work (Wheaton, Illinois: Crossway, 2011).

${ }^{\mathrm{x}}$ Douglas Jacobsen and Rhonda Hustedt Jacobsen, No Longer Invisible: Religion in University Education (Oxford: Oxford University Press, 2012), p. 5.

${ }^{x i}$ Jason Felch and Ralph Frammolino, Chasing Aphrodite: The Hunt for Looted Antiquities at the World's Richest Museum (Boston: Houghton Mifflin Harcourt, 2011), p. 319 